\title{
Efficacy of Marine Bacteria against Pathogenic Bacteria
}

\author{
Rami HAMMOD ${ }^{1}$, Ahmed QARA ALI ${ }^{2}$, Badr Al ALI ${ }^{3}$ \\ ${ }^{I}$ Doctora Student, Dept. of Marine biology at HIMR, Tishreen University, Lattakia \\ ${ }^{2}$ Assistant Professor, Dept. of Marine biology at HIMR, Tishreen University, Lattakia, Syria \\ ${ }^{3}$ Assistant Professor, Dept. of Marine Chemistry at HIMR, Tishreen University, Lattakia, Syria
}

*Corresponding Author: Rami HAMMOD, Doctora Student, Dept. of Marine biology at HIMR, Tishreen University, Lattakia

\begin{abstract}
The study included the selection of local marine bacteria isolates that were isolated from the sediments of the coastal waters of Lattakia, and theiridentity was determined using a number of agricultural, morphological and biochemical tests as being species belonging to the genus Bacillus. The inhibitory activity of different concentrations of the organic extracts of these bacterial isolates against some pathogenic bacteria (Streptococcus pneumoniae and Staphylococcus aureus) and Gram-positive bacteria (Escherichia coli, Pseudomonas aeruginosa, Klebsiella pneumonia) were studied using the gram-negative diffusion method. The inhibitory effect of this organic extract was then compared to that of some commercial antibiotics.The results showed that the biological activity of the organic extract of isolates of the genus Bacillus sp (B. subtilis, B. polymyxa, B. cereus, B. circulans) showed that the largest inhibition halo diameter of B. subtilis extract towards $S$. aureus was $26 \mathrm{~mm}$ and it was the lowest halo diameter for bacteria. P. aeruginosa was $13 \mathrm{~mm}$. As for B. polymyxa extract, the highest inhibition halo diameter was $27 \mathrm{~mm}$ against $S$. pneumoniae and $25 \mathrm{~mm}$ against $S$. aureus, and the lowest diameter of inhibition was recorded as $13 \mathrm{~mm}$ against P. aeruginosa. In relation to the extracts of other species of the genus Bacillus sp (B. cereus, B. circulans), the inhibitory activity of their extracts was higher against Gram-positive bacteria than against Gram-negative bacteria. These bacterial extracts of Bacillus sp were more effective than various commercial antibiotics used.
\end{abstract}

Keywords: Bacillus, Antibacterial activity, pathogenic bacteria.

\section{INTRODUCTION}

HOceans cover about $71 \%$ of the Earth's surface, and seas and oceans provide a tremendous diversity of microbial organisms [18]. The seas and oceans are an important resource of biodiversity that goes well beyond terrestrial environments. It possesses a unique and large group of diverse natural products produced by marine microorganisms [8], [9]. This marine biodiversity is reflected through the chemical diversity and efficacy of organic extracts against bacterial pathogens [7] The rapid development of marine organisms chemistry over the past fifteen years has led to the discovery of a large number of chemical compounds, which have pharmacokinetic, medicinal and toxicological properties towards previously unknown pathogenic human bacteria [16], [20]

Despite the great success achieved by the discovery of antibiotics and the development of the pharmaceutical industries in overcoming diseases resulting from microbial infections, many diseases are still waiting for effective treatment, and this is due to two main reasons, the first is the development of resistant or multi-resistant bacterial strains. The second is the emergence of new diseases whose treatment is still awaiting the discovery and development of suitable new drugs, hence the urgent need for continued research and development in this area [1], [7]

Therefore, it was necessary to study the effect of the organic extracts of the species of Bacillus $s p$ bacteria isolated from marine sediments on some pathogenic bacteria and compare them with commercial antibiotics.

\section{AIM AND IMPORTANCE OF RESEARCH}

Obtaining pure bacterial isolates of Bacillus $s p$ from marine sediments.

The effect of organic extracts of Bacillus $s p$ isolates on some pathogenic bacteria and their comparison with commercial antibiotics. 
The importance of research stems in investigating new sources of microorganisms of marine origin, especially the species of the genus Bacillus $s p$ that enjoy the production of chemical compounds that affect pathogenic bacteria. These new chemical compounds could be biologically effective and are the source for the development of many medicinal drugs, and thus are similar to effective antibiotics. It is important to investigate and obtain new natural materials from microorganisms, especially species of the genus Bacillus sp of marine origin.

\section{RESEARCH MATERIALS AND METHODS}

\subsection{Isolation and Diagnosis of Marine Bacillus sp}

Samples of marine water sediments were collected using sterile plastic bags from a depth of $10-20 \mathrm{~cm}$ from the beach of Lattakia city from Apamea region, as a site exposed to contamination with sewage water, during the sea launch in October of 2019. The sediment samples were transported directly to the laboratories of Tishreen University for laboratory analysis.

Taking $10 \mathrm{~g}$ from each sediment sample to obtain bacterial isolates from marine Bacillus $s p$, and adding to it $90 \mathrm{ml}$ of sterile distilled water in a $250 \mathrm{ml}$ glass beaker, mixed well, then heated the beaker in a water bath at a temperature of $80^{\circ} \mathrm{C}$ for half 1 hour to get rid of marine bacterial vegetative cells. Then $1 \mathrm{ml}$ of the diluted samples was transferred to test tubes containing $9 \mathrm{ml}$ of sterile Nutrient brouth. These tubes were then incubated at $30^{\circ} \mathrm{C}$ for 3 days. The tubes were examined by observing the formation of a thin white film close to the surface, which is a primary indicator of the growth of Bacillus sp [13], [21] Then $0.1 \mathrm{ml}$ of tubes that gave an indication of bacterial growth was taken and spread on the surface of a Petri dish containing nutrient agar medium and the plates were incubated at a temperature of $30^{\circ} \mathrm{C}$ for 24 hours [6] The developing colonies were selected, purified, and identified by studying the shape, color and growth of the colonies on the medium, and by performing a number of biochemical tests and comparing the results with Berge's evidence [14]

\subsection{Preparation of Extracts of Bacillus sp}

The different isolated Bacillus sp colonies were transferred to a beaker containing $100 \mathrm{ml}$ of peptone water medium and incubated at $30^{\circ} \mathrm{C}$ for 72 hours. The filtrate was separated from the sediment composed of bacterial cells after incubation using a centrifuge (5000 r / min). And for 10 minutes) according to Demain (1977). The top layer (the filtrate) was taken which contains all the byproducts and antibiotics produced by the bacteria. It was stored at $-20^{\circ} \mathrm{C}$ until its use and its biological efficacy was tested against human pathogens [3], [11]

\subsection{Pathogens used in this Study}

The pathogenic bacterial isolates recorded in Table (1) were obtained from various disease samples from Tishreen University Hospital in Lattakia Governorate. Pathogenic bacteria isolates were diagnosed and laboratory, microscopic and biochemical examinations were performed based on the scientific references used to diagnose the bacteria [4], [12], [23] The initial diagnosis of pathogenic isolates was made by observing the colors, shape, nature, odor and diameter of the colonies formed on the plate, and a set of biochemical tests were used according to the methods reported by Forbes and MacFaddin, based on Burji evidence [6] [13]. Also, bacteriostatic sentences based on biochemical tests were used to identify the germs (BioMérieux API Staph, API 20 Strep, API 20E System, France).

Table 1. Human pathogenic microbes and their sources

\begin{tabular}{|c|c|}
\hline Source & Isolated pathogenic germs \\
\hline Wound smear & Staphylococcus aureus \\
\hline piss & Streptococcus pneumoniae \\
\hline piss & Proteus vulgaris \\
\hline Wound smear & Escherichia coli \\
\hline Cerebrospinal fluid & Klebsiella pneumoniae \\
\hline Wound smear & Pseudomonas aeruginosa \\
\hline
\end{tabular}




\subsection{Study of the Inhibitory Activity of Extracts of Bacillus sp}

The sawing method was used in drilling (the cap assay method) according to Joreme and colleagues (2012) Liquid cultures of pathogenic bacteria were prepared in the middle of the nutritious broth and incubated at a temperature of $30^{\circ} \mathrm{C}$ for 24 hours, then 1100 were taken from these bacterial cultures and spread by sterile glass rod on the medium of Muller - Hinton agar (Merck Company, Germany), then the dishes were left to dry at a temperature Lab for 15 minutes. A sterile cork drill was used to make holes of mm6 in diameter in the medium distributed uniformly over the entire plate. Then I filled the holes with50 $\mu \mathrm{l}$ of the organic extract of each of the different isolated Bacillus sp types (B. subtilis $' B$. polymyxa $\triangle B$. cereus $` B$. circulans). The plates were then incubated at a temperature of $30^{\circ}$ $\mathrm{C}$ for 24 hours. The damping halos were then measured in millimeters around the holes to express the bioactivity of the organic extract [8][19]

\subsection{Sensitization of Pathogenic Bacteria Tested to Antibiotics}

This was done using the Vatik device (company, state) in the National Hospital of Lattakia Governorate (a little explanation of the mechanism is preferred).

\section{RESULTS AND DISCUSSION}

The results showed that the values of the biological activity of the organic extracts of Bacillus $s p$ isolates against the pathogenic bacteria ranged between $\mathrm{mm}(7-28)$ and the lowest was against $P$. vulgaris and the highest was against Strep bacteria. Faecalis (Table 2). This inhibitory activity was higher against Gram-positive pathogens compared to Gram-negative bacteria for all extracts of Bacillus $s p$ bacteria isolated (Table 2).

\subsection{For the Extract of Bacillus Subtilis Isolated from Apamea}

The results showed that the diameters of halos of growth inhibition of the pathogenic bacteria exposed to Bacillus subtilis extract ranged from 13-28 mm (Table 2 and Fig. 1). The largest observed halo diameter was $28 \mathrm{~mm}$ towards Strep. Faecalis, then to Staphylococcus aureus, was $26 \mathrm{~mm}$, the diameter of inhibition against $E$. coli was $24 \mathrm{~mm}$, and $21 \mathrm{~mm}$ was against $K$. pneumoniae, and $18 \mathrm{~mm}$ was against $P$. aeruginosa. As for $P$. vulgaris, it was $13 \mathrm{~mm}$.

\subsection{For Bacillus Polymyxa Extract Isolated from Apamea}

The results recorded in(Table 2 and Fig. 1). showed that the biological activity of this isolate extract against the pathogenic bacteria used ranged from 9-27 $\mathrm{mm}$. The largest diameter of the inhibition halo was $27 \mathrm{~mm}$ towards Strep bacteria. Faecalis, then $25 \mathrm{~mm}$ toward Staphylococcus aureus. While the lowest biological activity was $9 \mathrm{~mm}$ against $P$. aeruginosa.

\subsection{For Bacillus cereus isolated from Apamea}

1(Table 2 and Fig) show that the diameter of inhibition against Staphylococcus aureus was $23 \mathrm{~mm}$ and was $25 \mathrm{~mm}$ towards Strep. Faecalis, and that the diameter of the inhibition corona towards E. coli was $21 \mathrm{~mm}$, and that $20 \mathrm{~mm}$ was towards $\mathrm{K}$. pneumoniae, and that $10 \mathrm{~mm}$ was against $P$. aeruginosa. As for P. vulgaris, it was $12 \mathrm{~mm}$.

\subsection{For the extract of Bacillus Circulans Isolated from Apamea}

The results showed that the bioactivity of this organic extract ranged between 7-19 mm (Table 2 and Fig. 1). The diameter of the inhibition against Staphylococcus aureus was $16 \mathrm{~mm}$ and was $19 \mathrm{~mm}$ towards Strep. faecalis, and the diameter of the inhibition corona was $9 \mathrm{~mm}, 13 \mathrm{~mm}$ was towards $K$. pneumoniae, and $\mathrm{mm} 8$ was against $P$. aeruginosa. As for $P$. vulgaris, it was $7 \mathrm{~mm}$.

Table (2): The biological activity of the organic extracts of Bacillus sp isolates against the pathogenic bacteria was estimated by the diameter of the growth inhibition halos ( $\mathrm{mm})$.

\begin{tabular}{|c|c|c|c|c|c|c|}
\hline $\begin{array}{c}P . \\
\text { vulgaris }\end{array}$ & $\begin{array}{c}P . \\
\text { aeruginosa }\end{array}$ & K. pneumoniae & E. coli & $\begin{array}{c}S . \\
\text { faecalis }\end{array}$ & S. aureus & \\
\hline 16 & 13 & 21 & 24 & 28 & 26 & $\begin{array}{c}\text { B. } \\
\text { subtilis }\end{array}$ \\
\hline 10 & 9 & 18 & 22 & 27 & 25 & $\begin{array}{c}B . \\
\text { polymyxa }\end{array}$ \\
\hline 12 & 10 & 20 & 21 & 25 & 23 & $\begin{array}{c}\text { B. } \\
\text { cereus }\end{array}$ \\
\hline 7 & 8 & 13 & 9 & 19 & 16 & $\begin{array}{c}\text { B. } \\
\text { circulans }\end{array}$ \\
\hline
\end{tabular}


The results showed that the inhibitory activity values of all organic extracts against Gram-positive pathogenic bacteria were higher than that of Gram-negative bacteria (Table 2).

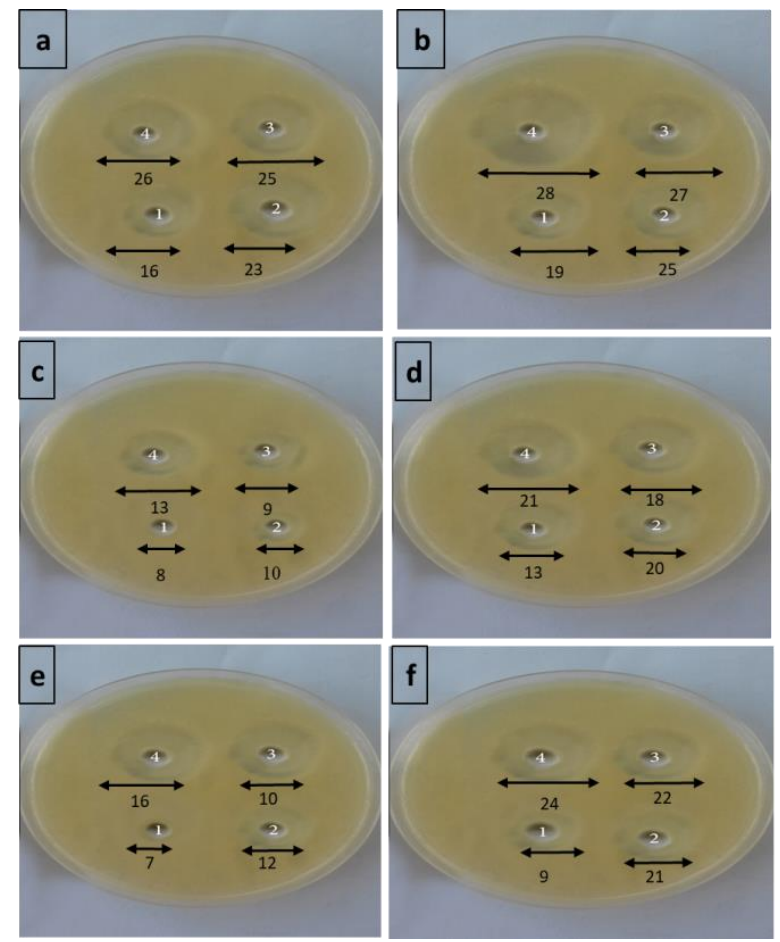

Figure1. Effect of extracts of Bacillus sp species isolated from Apamea region (extract (1) B. circulans, (2) B. cereus, (3) B. polymyxa, (4) B. subtilis) on pathogenic bacteria ( (a) S aureus, (b) S. faecalis, (c) P. aeruginosa, (d) K. pneumoniae, (e) P. vulgaris, (f) E. coli).

\section{RESULTS OF PATHOGEN SENSITIVITY TO ANTIBIOTICS}

\subsection{Staphylococcus aureus}

Staphylococcus aureus showed sensitivity only to two antibiotics, Trimethoprime-Sulfamethoxazole and Vancomycin, and showed moderate sensitivity to Levofloxacin (Table 3).

\subsection{Streptococcus pneumoniae}

Streptococcus pneumoniae showed resistance to the following antibiotics Cloxacillin, Ciprofloxacin, Levofloxacin and Amikacin and moderate sensitivity to Gentamycin (Table 3). This result is consistent with many studies that have shown resistance to beta-lactam antibiotics (penicillins and cephalosporins) of staphylococci and streptococcus, which are widely used in the treatment of various infections, in addition to their resistance to many other antibiotics [5] [2]

\subsection{Common Proteus vulgaris}

Only the common Proteus showed moderate sensitivity to Ampicillin-Sulbactam (Table 3). Other studies have shown that most of the antibiotics commonly used to treat infections caused by Proteus vulgaris have become ineffective [15] [25] note that all common Proteus strains are resistant to penicillin, ampicillin and oxacillin. More than $80 \%$ of them were resistant to gentamicin and ciprofloxacin and 50\% to amikacin, and this is due to the misuse of antibiotics or wrong prescriptions, and this pattern of resistance is associated with the occurrence of genetic mutations and the transmission of resistance genes between species through plasmids [22] [23]

\subsection{Escherichia coli}

Coli bacilli were only sensitive to Levofloxacin, Amikacin and Ciprofloxacin (Table 3). The E. coli strains producing beta-lactamase in Dash et al. (2012) and Kaur and Anu (2016) showed resistance to gentamicin and amikacin, and showed moderate sensitivity to Ciprofloxacin. Coli bacilli in Cunha et al. (2016) also showed resistance to the antibiotic Trimethoprime-Sulfamethoxazole. These results give cause for concern as Ciprofloxacin is the most effective treatment for urinary infections .[21] [10] 


\subsection{Pseudomonas aeruginosa}

The results showed that all strains of Pseudomonas aeruginosa were resistant to a large number of antibiotics, as in the study of Bernal-Rosas and colleagues (2015). It showed complete resistance to Cefazolin, Lincomycin, Cephalothin, Ampicillin, Clindamycin, and Chloramphenicol. It also showed moderate sensitivity to Sulfamethoxazole-Trimethoprim (Table 3).

The results of the study by Lin and colleagues (2012) and Rakesh et al. (2012) showed a low percentage of strains resistant to these two antibodies, while they showed moderate sensitivity to gentamicin, but they were sensitive to amikacin in the current study.

\subsection{Klebsiella pneumoniae}

Klebsiella pneumoniae showed sensitivity to only two antibiotics, Levofloxacin and Amikacin (Table 3). This is in agreement with the results of a study by Cunha et al. (2016) which showed that most strains of Klebsiella are resistant to Ciprofloxacin and Trimethoprime-Sulfamethoxazol, and moderate sensitivity to Oxacillin. While it showed high sensitivity to the antibiotic Amikacin.

The fact that these bacteria possesses resistant plasmids of penicillins and aminoglycosides and the occurrence of chromosomal kmutations confer resistance to fluoroquinolones and narrows the field of choice of effective treatment [5], [14]

The proliferation of antibiotic-resistant bacteria is mainly attributed to their continuing effect on the same cellular sites (the fact that all the antibiotics used affect the bacterial cell by one of the four known mechanisms: inhibition of cell-wall synthesis and metabolic processes, inhibition of bacterial protein synthesis, and finally, inhibition of synthesis of nucleic acids). This leads to mutations of bacterial genes [11], [26] . This is in agreement with recent data from the World Health Organization (2014) and the Centers for Disease Control (CDC).

Table3. Allergy of pathogenic bacteria to a number of antibiotics

\begin{tabular}{|c|c|c|c|c|c|c|}
\hline P. aeruginosa & K. pneumoniae & E. coli & P. vulgaris & $\begin{array}{c}\text { Strep. } \\
\text { Faecalis }\end{array}$ & $\begin{array}{l}\text { Staph. } \\
\text { Aureus }\end{array}$ & \\
\hline 0 & 11 & 0 & 7 & 19 & 0 & \multirow{2}{*}{$\mathrm{AX}$} \\
\hline $\mathrm{R}$ & I & $\mathrm{R}$ & $\mathrm{R}$ & $\mathrm{S}$ & $\mathrm{R}$ & \\
\hline 0 & 9 & 0 & 0 & 10 & 0 & \multirow[b]{2}{*}{$\mathrm{Cx}$} \\
\hline $\mathrm{R}$ & $\mathrm{R}$ & $\mathrm{R}$ & $\mathrm{R}$ & $\mathrm{R}$ & $\mathrm{R}$ & \\
\hline 0 & 0 & 0 & 13 & 16 & 0 & \multirow{2}{*}{ SAM } \\
\hline $\mathrm{R}$ & $\mathrm{R}$ & $\mathrm{R}$ & I & $\mathrm{S}$ & $\mathrm{R}$ & \\
\hline 0 & 12 & 0 & 0 & 24 & 0 & \multirow{2}{*}{$\mathrm{CE}$} \\
\hline $\mathrm{R}$ & $\mathrm{R}$ & $\mathrm{R}$ & $\mathrm{R}$ & $\mathrm{S}$ & $\mathrm{R}$ & \\
\hline 0 & 9 & 0 & 0 & 22 & 12 & \multirow{2}{*}{ CEC } \\
\hline $\mathrm{R}$ & $\mathrm{R}$ & $\mathrm{R}$ & $\mathrm{R}$ & $\mathrm{S}$ & $\mathrm{R}$ & \\
\hline 10 & 0 & 9 & 0 & 27 & 0 & \multirow{2}{*}{ CXM } \\
\hline $\mathrm{R}$ & $\mathrm{R}$ & $\mathrm{R}$ & $\mathrm{R}$ & $\mathrm{S}$ & $\mathrm{R}$ & \\
\hline 12 & 0 & 0 & 9 & 18 & 0 & \multirow{2}{*}{ CFM } \\
\hline $\mathrm{R}$ & $\mathrm{R}$ & $\mathrm{R}$ & $\mathrm{R}$ & $\mathrm{S}$ & $\mathrm{R}$ & \\
\hline 10 & 11 & 0 & 10 & 22 & 9 & \multirow{2}{*}{$\mathrm{CRO}$} \\
\hline $\mathrm{R}$ & $\mathrm{R}$ & $\mathrm{R}$ & $\mathrm{R}$ & $\mathrm{S}$ & $\mathrm{R}$ & \\
\hline 23 & 8 & 18 & 12 & 12 & 11 & \multirow{2}{*}{ CIP } \\
\hline $\mathrm{S}$ & $\mathrm{R}$ & I & $\mathrm{R}$ & $\mathrm{R}$ & $\mathrm{R}$ & \\
\hline 19 & 18 & 24 & 10 & 10 & 15 & \multirow{2}{*}{ LEV } \\
\hline $\mathrm{S}$ & $S$ & $S$ & $\mathrm{R}$ & $\mathrm{R}$ & I & \\
\hline 18 & 18 & 17 & 10 & 14 & 9 & \multirow{2}{*}{$\mathrm{AK}$} \\
\hline$S$ & $S$ & $S$ & $\mathrm{R}$ & $\mathrm{R}$ & $\mathrm{R}$ & \\
\hline 14 & 7 & 8 & 10 & 13 & 0 & \multirow{2}{*}{$\mathrm{CN}$} \\
\hline I & $\mathrm{R}$ & $\mathrm{R}$ & $\mathrm{R}$ & $\mathrm{I}$ & $\mathrm{R}$ & \\
\hline 9 & 0 & 10 & 0 & 26 & 17 & \multirow{2}{*}{ VA } \\
\hline $\mathrm{R}$ & $\mathrm{R}$ & $\mathrm{R}$ & $\mathrm{R}$ & $\mathrm{S}$ & $\mathrm{S}$ & \\
\hline 13 & 8 & 0 & 0 & 16 & 22 & \multirow{2}{*}{ SXT } \\
\hline I & $\mathrm{R}$ & $\mathrm{R}$ & $\mathrm{R}$ & $\mathrm{S}$ & $\mathrm{S}$ & \\
\hline
\end{tabular}




\section{CONCLUSIONS AND RECOMMENDATIONS}

From this study we conclude that the extracts of species of the genus Bacillus sp (B. subtilis, $B$. polymyxa,B. cereus, B. circulans, B. megaterium) had higher inhibitory activity against Gram-positive bacteria than Gram-negative bacteria.

The extract of type $B$. subtilis showed higher bioactivity than the other organic extracts of the genus Bacillus sp.

Bacterial extracts of the genus Bacillus $s p$ also showed higher bioactivity than various commercial antibiotics.

This result confirms the need to search and investigate natural sources of antibiotics that have an effective effect against pathogenic germs and have no harmful effects on human health.

\section{REFERENCES}

[1] ANSARUZZAMAN, M.; NAIR, G.B. and ENDRZ, H.P. Antibacterial Substance Produced Pseudomonas aeruginosa with High In-Vitro Antimicrobial Activity against Vibrio cholera O1 and O139. ScientificSession, 1 February. 2010. http://www.sciencedirect.com/.

[2] APPELBAUM, P.C. Reduced Glycopeptide Susceptibility in Methicillin-ResistantStaphylococcus aureus (MRSA). International Journal of Antimicrobial Agents, Vol.30, 2007, 398-408.

[3] BUCHANAN, R. E. and GIBBONS, N. E. Bergey's Manual of DeterminativeBacteriology. Eight Edition, William \& Wilkins, Baltimore, USA., 1974, 1-573.

[4] CUNHA, M.A.; ASSUNCAO, G.L.M.; MEDEIROS, I.M. and FREITAS, M.R. Antibiotic Resistance Patterns of Urinary Tract Infections in a Northeastern Brazilian Capital. Rev. Inst. Med. Trop. Sao Paulo, Vol. 58, No. 2, 2016, 1-4.

[5] DASH, S.K.; CHAKRABORTY, S.P.; MANDAL, D. and ROY, S. Isolation and Characterization of Multi Drug Resistant Uropathogenic Escherichia coli from Urine Sample of Urinary Tract Infected Patients. International Journal of Life Science \& Pharma Research, Vol. 2, No. 1, 2012, 25-39.

[6] GAD, A.; BELTAGY, E.; ABDUL-RAOUF, U.; EL-SHENAWY, M. and ABOUELKHEIR, S. Screening of Marine Fatty Acids Producing Bacteria with Antimicrobial Capabilities. Chemistry of Advanced Materials, Vol. 1, No.2, 2016, 41-54.

[7] GARRITY, G.M.; BELL, J.A. and LIBURRN, T.G. Taxonomic Outline of the Prokaryotes Bergey's Manual of Systematic Bacteriology. $2^{\text {nd }}$ Edition, Springer, New York BerlinHeidelberg, 2004, 401.

[8] IBTISSAM, C.; HASSANE, R.; JOSÉ, M-L.; FRANCISCO, D.S.J.F.; ANTONIO, G.V.J.; HASSAN, B. and MOHAMED, K. Screening of Antibacterial Activity in Marine Green and Brown Macroalgae from the Coast of Morocco. African Journal ofBiotechnology, Vol. 8, No. 7, 2009, 1258-1262.

[9] KABORE, W.A.D.; BAGRE, T.S.; KONATE, A.; TRAORE, R.G.; BAKO, E.; KONSEM, T.; BOISRAME, S.; TRAORE, A.S.; BARRO, N. and SANGARE, L .Characteristics of Streptococcus and Staphylococcus strains Isolated from Acute Cellulitis of Dental Origin in Ouagadougou, Burkina Faso. African Journal of Microbiology Research, Vol. 10, No. 9, 2016, 292-300.

[10] KATZ, E. and DEMAIN, A.L. The Peptide Antibiotics of Bacillus: Chemistry, Biogenesis, and Possible Functions. Bacteriology Reviews, Vol. 41, No. 2, 1977, 449-474.

[11] KAWAMOTO, J.; KURIHARA, T.; YAMAMOTO, K.; NAGAYASU, M.; TANI, Y.; MIHARA, H.; HOSOKAWA, M.; BABA, T.; SATO, B. and ESAKI, N. Eicosapentaenoic Acid Plays a Beneficial Role in Membrane Organization and Cell Division of a Cold-Adapted Bacterium, Shewanella livingstonensis Ac10. Journal of Bacteriology, Vol. 191, No. 2, 2009, 652-640.

[12] NCCLS. Performance Standards for Antimicrobial Susceptibility Testing. Fourteenth informational supplement. Vol. 24, No. 1, 2004.

[13] OBEROI, S.S.; DHINGRA, C.; SHARMA, G. and SARDANA, D. Antibiotics in Dental Practice: How Justified Are We?. Vol. 65, 2015, 4-10.

[14] ONBASLI, D. and ASLIM, B. Determination of Antimicrobial Activity and Production of Some Metabolites by Pseudomonas aeruginosa B1 and B2 in Sugar Beet Molasses. African Journal of Biotechnology, Vol. 7, No. 24, 2008, 4614-4619.

[15] RICE, L.B. Antimicrobial Resistance in Gram-Positive Bacteria. The American Journal of Medicine, Vol. 119, No. 6, 2006, 11-19. 
[16] SAHA, S.; THAVASI, R. and JAYALAKSHMI, S. Phenazine Pigments from Pseudomonas aeruginosa and Their Application as Antibacterial Agent and Food Colourants. Research Journal of Microbiology, Vol. 3, No.3, 2008, 122-128.

[17] SAOSOONG, K.; WONGPHATHANAKUL W.; POASIRI, C. and RUANGVIRIYACHAI, C. Isolation and Analysis of Antibacterial Substance Produced from $P$. aeruginosa TISTR 781. KKU Science Journal, Vol. 37, No. 2, 2009, 163-172.

[18] SCHOENTAL, R. The Nature of the Antibacterial Agents Present in Pseudomonas pyocyaneus Culture. The British Journal of Experimental Pathology, Vol. 22, No. 3, 1941, 137-147.

[19] THOMSON, J.M. and BONOMO, R.A. The Threat of Antibiotic Resistance in Gram Negative Pathogenic Bacteria: $\beta$-lactams in peril!. Current Opinion in Microbiology, Vol. 8, No. 5, 2005, 518-524.

[20] Todar, K. Todar's on line Textbook of Bacteriology University of Wisconsin-Madison, Department of Bacteriology, 2003.

[21] UZAIR, B.; AHMED, N.; KOUSAR, F. and EDWARDS, D.H. Isolation and Characterization of Pseudomonas Strain That Inhibit Growth of Indigenous and Clinical Isolate. The Internet Journal of Microbiology, Vol. 2, No. 2, 2006. 16 February. 2011. http://www.sciencedirect.com/.

[22] WHO. Antimicrobial Resistance: Global Report on Surveillance. World Health Organization, 2014, 1-232.

[23] WHO. The Evolving Threat of Antimicrobial Resistance Options for Action. World Health Organization. 2012, 1-125.

[24] WHO. The WHO Policy Package to Combat Antimicrobial Resistance. Geneva. World Health Organization, 2011.

[25] YANG, R.-Y.; LI, C.-Y.; LIN, Y-C.; PENG, G.-T.; SHE, Z.-G. and ZHOU, S.-N. Lactones from a Brown Alga Endophytic Fungus from the South China Sea and Their Antimicrobial Activities. Bioorganic \& Medicinal Chemistry Letters, Vol. 16, No. 36, 2006, 4205-4208.

[26] ZHENG, L.; HAN, X.; CHEN, H.; LIN, W. and YAN X. Marine Bacteria Associated with Marine Macroorganisms: the Potential Antimicrobial Resources.Annals ofMicrobiology, Vol. 55, No. 2, 2005, 119-124.

[27] DASH, S.K.; CHAKRABORTY, S.P.; MANDAL, D.; ROY, S. Isolation and Characterization of Multi Drug Resistant Uropathogenic Escherichia coli from Urine Sample of Urinary Tract Infected Patients. International Journal of Life Science \& Pharma Research, Vol. 2, No. 1, 2012, 25-39.

Citation: Rami HAMMOD et al." Efficacy of Marine Bacteria against Pathogenic Bacteria", International Journal of Innovative Studies in Aquatic Biology and Fisheries (IJISABF), vol. 7, no.2, pp. 12-18, 2021. http://dx.doi.org/10.20431/2454-7670.0702002

Copyright: () 2021 Authors. This is an open-access article distributed under the terms of the Creative Commons Attribution License, which permits unrestricted use, distribution, and reproduction in any medium, provided the original author and source are credited. 